\title{
Should Organisations Compete or Collaborate when Absorbing New External Knowledge?
}

http://dx.doi.org/10.3991/ijac.v8i3.4741

\author{
Muhammad Rafique ${ }^{1}$, Richard David Evans ${ }^{2}$, Muhammad Tahir Nawaz ${ }^{1}$, Mujtaba Hassan Agha ${ }^{3}$ \\ ${ }^{1}$ National University of Science and Technology, Islamabad, Pakistan \\ ${ }^{2}$ University of Westminster, UK \\ ${ }^{3}$ Muhammad Ali Jinnah University, Islamabad, Pakistan
}

\begin{abstract}
Organisations possessing significant resources (Resource Based View) or knowledge, as their significant capability (Dynamic Capability View), are often unaware of their own ability to acquire new knowledge entering the enterprise (level of absorptive capacity); this unawareness can lead to reduced marketplace performance and incorrect decision making, which may result in the wastage of organisational resources, including employee knowledge. This study highlights the key differences in absorptive capacity which firms possess, in the context of resource based and dynamic capability views. Based on these differing perspectives, options are provided for companies who wish to compete or mate/merge with competitors in the market, while discussion is given on the considerations that organisations must take before adopting a suggested option.
\end{abstract}

Index Terms-Absorptive Capacity, Business Decision Making, Knowledge Acquisition, Marketplace Competition.

\section{INTRODUCTION}

Organisations operating in today's turbulent business environment follow one of two trains of thought when competing against competitors in the marketplace: 1) a Resource Based View (RBV) or 2) extended from the $\mathrm{RBV}$, referred to as Dynamic Capabilities (DC). Conceptually, a RBV follows the theme of a bundle of resources, both tangible and intangible, which are unique and valuable in nature and which are neither transferable nor imitable by a company's competitors [1, 2, 3, 4]. Firms which employ these resources when implementing difficult business strategies, produce products which are often innovative and difficult to duplicate or imitate [5]. DC, being an extension of $\mathrm{RBV}$, is conceptualized as a set of unique and idiosyncratic processes which exploit the resources of an organisation when competing with others in the marketplace [6].

Two expositions are clear from these approaches: 1) firms must maintain focus of their goals, referring to either long-term competitive advantage or sustained competitive advantage and 2) Resources are the basic ingredients in business strategies; therefore, on the basis of an organisation's resources, they can typically hold market position; the mere possession of resources, however, does not guarantee a firm achieving their goals effectively; additional factors, such as employee skills, work ethics, business processes, knowledge, and the adaptation to the surrounding environment are equally important [7].

Changes in the market demand the refinement of internal processes and the re-alignment of organisational resources, similar to new processes, which require new external knowledge to be captured from outside the firm; an organisation's ability to capture and process this new knowledge successfully is required in order for it to succeed. These capabilities are necessary for the up-gradation of a firm's intellectual and physical resources, which is termed as Absorptive Capacity (AC). Absorptive Capacity is the ability of an organisation to evaluate the importance of new externally-captured knowledge required to create new business processes and further implement processes across the organisation [8].

Firms often focus on resources, but intentionally or unintentionally, are often drawn to the building of their knowledge absorption capabilities. Absorptive capacity is the basic parameter which firms use when deciding to compete with their competitors and it's this difference in $\mathrm{AC}$ which leads them to adopt business processes to remain competitive.

Resources are considered a critical asset for survival and the allocation and continuous auditing of these lead an organisation to optimize, thus creating a balance between absorptive capacity and resources [9]. As organisational resources are often similar, their capabilities keep on changing and, therefore, are attributed as an important factor for successful competition. Firms which follow the RBV pathway possess absorptive capacity quite different from firms which follow a DC view. From a RBV, the primary focus of a company is often on uniqueness and the development of innovative, non-transferable valued resources and processes. These resources require different levels and nature of absorptive capacity, as compared to firms where absorptive capacity needs to be continually developed and updated to meet changes in the market to deal with the latest knowledge.

Firms with different focal points (RBV or DC) which are competing with firms with the same or different focal points may evaluate their performance in light of their absorptive capacity. If there is a divergence from target, they may transform their capabilities by fighting/competing with competitors and/or may collaborate (Business mate) with others in the market. This study considers all three aspects and discusses different options for firms with differing levels of absorptive capacity, thus aiming to answer the following question: What leads a firm to opt for differing activities, such as collaboration, transformation of capabilities and competition, when they find differences of absorptive capacity in comparison to competitors in perspective of resource based view and dynamic capabilities? 


\section{RESOURCE-BASED VIEW AND DYNAMIC CAPABILITIES}

The RBV of a firm refers to a set of resources which are Valuable, Rare, Inimitable, and Non-substitutable; this is commonly abbreviated as "VRIN" [3, 10, 11]. Firms which follow an RBV approach are considered a source of competitive advantage for long-term. A company's resource base, in terms of organisational capabilities, has been argued in literature as the effective network of a firm's capacities to deploy these resources effectively across their business processes [12]. Firms with a RBV focus primarily on the exploitation of these resources and strengthen their capabilities in a heterogeneous way, so that others are unable to replicate them. In strengthening these resources, internal research on value creation leads them to long-term competitive advantage, as compared to competitors who lack these resources; changes to a business to sustain competitive advantage depends on if existing or potential capabilities are VRIN [13].

Unlike the RBV, dynamic capability focuses on the integration, building and reconfiguring of corporate competences (both internal and external) [6, 14]. Companies following a DC approach aim to establish core competences in the short term in order to achieve-long term competitive advantage in the future [6].

In general, the difference between RBV and DC is that RBV deals with the static business environment where processes are similar and products are homogenous, whereas DC deals with dynamic markets, where customer demands and product designs are changing rapidly; both approaches need successful absorptive capacity in order to handle the situation of business for competitive advantage and sustain it for a long time.

\section{AC FROM THE PERSPECTIVE OF RBV AND DCV}

Absorptive capacity has been defined as the capability of an organisation to identify valued knowledge critical to its operations, assimilate it and apply it to commercial needs [8]. The concept of AC has been viewed in differing forms in research, ranging from the effective utilization of a business's resources and the skills of employees, to the capabilities of an organisation of handling fast changing knowledge entering the organisation $[15,16,17]$. Zahra and George [15] expanded on the definition of absorptive capacity, splitting it into four components: 1) Acquisition, 2) Assimilation, 3) Transformation and 4) Exploitation. According to Ferreras-Mendez et al. [18], absorptive capacity sandwiches itself between the process of exploring new external knowledge and the process of enhancing business capabilities, from both RBV and DC perspectives; thus creating a base line for interaction between different knowledge infrastructures.

Although firms continuously acquire knowledge, the utilization of resources and capabilities exactly define the type of absorptive capacity required by them. Firms following a RBV require constant up-gradation and strengthening of their unique resources as they focus on methods to make their resource capabilities distinguished, yet nontransferable; AC makes them achieve this goal through constant up-gradation. In this situation, the requirement is simple and, furthermore, small up-gradation in $\mathrm{AC}$ is required to be continuous. When a firm knows its future direction, the employment of resources in order to achieve new knowledge and embed it into business processes becomes easier. Absorptive capacity in this situation re- mains robust and guarantees fulfillment of business process needs.

The breadth of knowledge and the capability of an organisation to deal with knowledge infrastructures lead firms to innovate effectively [19], but absorptive capacity itself, depends on the type of knowledge infrastructure and capacity of managers to deal with different knowledge dimensions [20]. Firms often have factors directly or indirectly affecting their absorptive capacity capacity; Rafique et al. [21] explored the critical success factors required in the development of absorptive capacity in knowledge intensive environments.

The RBV focuses either on homogeneous business environments, both in stable and turbulent form, or heterogeneous environments with small drifts; both situations are considered as static business environments and the building or consolidation of absorptive capacity in this environment may be referred to as Static Absorptive Capacity (SAC).

The DC view refers to dealing with knowledge required for a firm's processes to meet the requirements in changing business environments. Firms competing with DC require their absorptive capacity to be enhanced at least at the same speed as the business dynamics are changing [22]. In this situation, business dynamics grow with greater uncertainties, as compared to in a RBV, where changes are either small or large, but in a uniform and systematic way. A firm's ability to absorb external knowledge is time and context specific, which means at one particular time and for one particular product, the AC is different than if the product or time changes. In this situation, absorptive capacity becomes volatile as specifically for one changed product or design change as per market demand would require another set of absorptive capacity [23].

Similarly, to deal with different products, different skills and expertise is required in the context of absorptive capacity. Developing absorptive capacity to meet constantly changing requirements during the strategic innovation [24] is termed as Dynamic Absorptive Capacity (DAC); the differences between SAC (RBV) and DAC (DC View) are displayed in Table 1.

\section{TABLE I. AC DIFFERENCE IN RBV AND DC VIEWS}

\begin{tabular}{|c|c|}
\hline Static AC - RBV View & Dynamic AC - DC View \\
\hline $\begin{array}{l}\text { - Based on the consolidation of } \\
\text { resources. }\end{array}$ & $\begin{array}{l}\text { - Based on the consolidation of } \\
\text { skills. }\end{array}$ \\
\hline $\begin{array}{l}\text { - Absorptive capacity building } \\
\text { is slow and incremental, but } \\
\text { with high consolidation as the } \\
\text { resources are known and man- } \\
\text { agers know exactly what their } \\
\text { processes need and at what } \\
\text { speed and intensity. }\end{array}$ & $\begin{array}{l}\text { - Absorptive capacity is dy- } \\
\text { namic in nature and every } \\
\text { time an introduction of a new } \\
\text { product or change of design is } \\
\text { required, different nature of } \\
\text { requirements are generated } \\
\text { [17]. }\end{array}$ \\
\hline $\begin{array}{l}\text { Non-volatile for prolonged } \\
\text { period if there is no major } \\
\text { changes in the designs of } \\
\text { products. }\end{array}$ & $\begin{array}{l}\text { Volatile because of dynamic } \\
\text { environments, as consolida- } \\
\text { tion is difficult due to fast } \\
\text { changing market demands in } \\
\text { design and variety of prod- } \\
\text { ucts. }\end{array}$ \\
\hline $\begin{array}{l}\text { - Features of absorptive capaci- } \\
\text { ty (direction, speed and inten- } \\
\text { sity) as highlighted by Zahra } \\
\text { and George [15] are easy to } \\
\text { achieve because of confidence } \\
\text { in sustained and unique capa- } \\
\text { bilities. }\end{array}$ & $\begin{array}{l}\text { - Features may be compro- } \\
\text { mised because of dynamic } \\
\text { environment as speed and } \\
\text { intensity depend directly on } \\
\text { direction of employment of } \\
\text { skills and focal point under } \\
\text { consideration as per new re- } \\
\text { quirement of market. }\end{array}$ \\
\hline
\end{tabular}


PAPER

SHOUld ORGANiSATIONS COMPETE OR COLlabORATE WHEN ABSORBING NEW EXTERnAl KNOWLEDGE?

\begin{tabular}{|c|c|}
\hline $\begin{array}{l}\text { - Chances of success are high } \\
\text { for firms with high absorptive } \\
\text { capacity as compared to firms } \\
\text { with low absorptive capacity } \\
\text { as resources are unique in na- } \\
\text { ture and may not copied. }\end{array}$ & $\begin{array}{l}\text { - Chances of success depend } \\
\text { upon the previous absorptive } \\
\text { capacity and intensity of } \\
\text { skills for new upcoming } \\
\text { products. }\end{array}$ \\
\hline $\begin{array}{l}\text { Works well in homogeneous } \\
\text { business environment and not } \\
\text { fit for heterogeneous environ- } \\
\text { ment. }\end{array}$ & $\begin{array}{l}\text { - Works well in homogeneous } \\
\text { as well as heterogeneous } \\
\text { business environment. }\end{array}$ \\
\hline $\begin{array}{l}\text { - Acquisition, assimilation and } \\
\text { transformation of new } \\
\text { knowledge inside the firm is } \\
\text { easy and requires less efforts } \\
\text { because of possession of } \\
\text { unique resources provided the } \\
\text { direction of flow of knowledge } \\
\text { is right. Exploitation of } \\
\text { knowledge needs extra efforts } \\
\text { as stereotype products and } \\
\text { processes are competing in } \\
\text { static as well as in dynamic } \\
\text { markets. }\end{array}$ & $\begin{array}{l}\text { Acquisition and assimilation } \\
\text { of knowledge depends on } \\
\text { intensity of efforts and diver- } \\
\text { sity of skills of firms. How- } \\
\text { ever, transformation and ex- } \\
\text { ploitation is comparatively } \\
\text { easy as the firms possess dy- } \\
\text { namic capabilities. }\end{array}$ \\
\hline $\begin{array}{l}\text { - Development of absorptive } \\
\text { capacity is incremental. }\end{array}$ & $\begin{array}{l}\text { Development of absorptive } \\
\text { capacity is dependent on type } \\
\text { of product or new market } \\
\text { demand [25]. }\end{array}$ \\
\hline
\end{tabular}

\section{ABSORPtive CAPACITY AND Adoption OF BusinesS MATE OR BUSINESS FIGHT OPTIONS}

Each aspect of AC (static and dynamic) leads a firm to follow different options, both in terms of competition and collaboration; these aspects are now discussed.

\section{A. Firms with Business Fight Option}

Firms compete with competitors on the basis of their capabilities (absorptive capacity) and effective exploitation of their resources, through these capabilities. Capability employment plays an important role in successful market competition. Firms with varying absorptive capacity compete with different options, as explained in the subsequent sections. Table 2 displays a competition matrix, whereby each icon explains a particular scenario in competition.

1) Static Absorptive Capacity vs. Static Absorptive Capacity ( $R B V V S R B V)$

In the case of firms which have the same resources and operate in a similar business environment, it is often the case that they have less developed resources. The absorptive capacity of both companies may vary, but the firm which possesses stronger absorptive capacity may have a greater edge over its competitors; these firms focus on the development of innovative processes, whilst keeping in view of the limited resources they hold. They use their skills in order to align their intangible assets with their tangible ones more effectively. They have to compete in a business environment along with new innovations and, therefore, keep their resources and efforts at an optimized level. Resource allocation is one of the key components of absorptive capacity and must be carried out effectively to compete; therefore, firms must improve the management of their resources and assets to compete and give them a competitive edge and greater market share. As the competing firms have almost the same set of resources, and on the basis of their existing resources, they have to compete with each other whilst keeping track of the performance of one another. They change their processes and align their resources with a view to compete and become a market leader, based on their ability to absorb new external knowledge. Firms which manufacture consumer-focused products, such as tooth paste, stationary items inter alia fall into this category of competition. The distinction of firms is achieved by strengthening absorptive capacity in view of the following:

- Internal processes of firms (focus on assimilation of newly acquired knowledge);

- Focused approach aligned with customer demands (exploitation of firm's knowledge; one of the components of absorptive capacity);

- Continuous up-gradation of knowledge processes through acquisitions (one of the important ingredients of absorptive capacity); and

- Focus on customer needs and put their efforts into conforming to the specifications of customers (Transformation components of absorptive capacity).

In this environment, the fight among customers is based on an organisation's resources. Firms try to develop uniqueness in certain processes and skills, and effectively use their resources to compete and become successful.

The base of fight is the uniqueness of resources on both sides (firms and their competitors) and firms which exploit these resources based on absorptive capacity. The market position of a company depends upon their resources, and the resources for particular products are almost similar in nature, hence it is the pushing and pulling of resources by the firms in this competition, hence the analogy of a 'bull fight'.

2) Static Absorptive Capacity vs. Dynamic Absorptive Capacity ( $R B V V S D C$ )

Firms operating with a RBV with static absorptive capacity and who are competing with firms possessing dynamic capabilities (dynamic absorptive capacity) create an extremely tough business environment for these firms. They exhaust their scarce resources, while competing with ambidextrous (based on dynamic capabilities) firms who are continuously carrying basic research to explore and develop processes to exploit existing knowledge bases.

Firms with an RBV capability focus on the innovation of existing processes, while optimizing their own resources. They often, however, have scarce resources and sometimes have greater innovative capabilities compared with their competitors, but this is related to the existing processes and focuses more on internal routine processes. Firms which have an edge in this competition are those with a uniqueness in product and its development over the period of time which is difficult to follow by firms possessing short-term knowledge applications. They manage intra-firm structures better, as compared to control on external factors. Their absorptive capacity is highly contextualized and thus they focus on a narrow but consolidated window of customers. They spend less on the exploration of new knowledge through basic research because of specialized resources or capabilities for the specific domain. The only fear they possess is that technologies become obsolete or that there is a paradigm shift in technology. For example, firms leading in the analog technology market of still cameras could not realign their capabilities with the new technological changes and had to keep on competing with their existing resources and capabilities. They were heading towards failure as analog camera 
technology was being replaced with digital camera (paradigm shift).

Another important success factor is that of brand uniqueness and brand loyalty. Firms focus on their unique products and to break the thrust of their uniqueness, competitors pull the customers towards them with differing incentives, such as cheaper prices, diverse product features and simple and user-friendly modules. Therefore, a firm's success depends upon static, but consolidated absorptive capacity, while keeping customers changing demands and technology related to their core products.

3) Dynamic Absorptive Capacity vs. Static Absorptive Capacity (DC VS RBV)

Firms which have dynamic capabilities (DC capacity) and who are competing with firms with a RBV (static AC) often have an edge over competitors, both in terms of the technology which they employ and the resources they possess. They possess capabilities to meet changing market demands, however, they often compete with firms having more robust resource infrastructures and yet inimitable. They might have a strong grip on the market with their well-established infrastructure. Firms possessing dynamic absorptive capacity either have to restrict themselves to products or remain close to competitors by molding or narrowing down dynamism of their absorptive capacity and compromise their diverse approach. In this case, they will have to make tradeoffs between competition with traditional competitors in products and core capability of dynamism, losing the opportunities in an open environment (competing with rivals with dynamic absorptive capacity).

Firms with dynamic absorptive capacity have an option to compete either with firms having static absorptive capacity or firms with dynamic absorptive capacity; they have the option to compete with their competitors with both dynamic and static views, at the same time. For this to happen, they must transform their AC from one form to the other. Firms may designate specific resources to develop and deal with both types of absorptive capacity (static and dynamic) to compete with competitors in each domain at the same time. For example, Apple transformed their absorptive capacity (static absorptive capacity in computer domain) to new dynamic absorptive capacity (mobile technology domain) and now out-perform competitors and have become the market leader in the smart phone market. Mobile phone companies, such as Nokia and Samsung, with traditional path dependent absorptive capacity (static in nature), were dominated by Apple with dynamic capabilities (static as well as dynamic), thus had a dominating market position.

4) Dynamic Absorptive Capacity vs. Dynamic Absorptive Capacity ( DC VS DC)

Firms which are both ambidextrous and operate in a similar business environment to that of competitors are continuously changing. The firms continuously invest in basic research to explore new knowledge required to meet the changing business environment. Firms operating in this environment focus on changing customer and market demands, as well as their competitor's strategy to exploit knowledge. The identification of critical knowledge and its assimilation at the right time is one of the success factors for firms competing in this environment. There is not a stopping point in the development of their absorptive capacity as stopping at any point would result in a change of pathway towards a negative side causing the firm to fail, if prolonged. Achieving competitive advantage may be sufficient, but not necessary here as 'aiming at sustained competitive advantage' is the only desirable position in the market. Therefore, there is a continuous race for sustainable competitive advantage, which is the only way to survive in this business environment.

Firms with increased dynamic AC may strengthen their market position, as compared to competitors, with less developed dynamic absorptive capacity. In the travel and mobile industries, companies often fall in to this category, as they focus on their customers and mold their processes accordingly, based on their absorptive capacity. A little deviation from this path leads the firms to deplete their share in the market. The Company, Pakistan Telecom (Paktel), was once the leading Telecoms Company in Pakistan, but had to close its operations during the introduction of new service packages by Nokia and Ufone. Internationally, the automobile and electronic industries fall in to this domain. Nissan, being a competitor in the automobile industry, when compromised in manufacturing processes, had to pay for heavy losses and only regained its position when it reorganized its resources. Strong competitors fighting with dynamic capabilities in turbulent environments include Shell and Caltex, Pepsi and Coca Cola, IBM and Oracle.

This type of environment, where ambidextrous firms compete, has the analogy of a Tigers Fight (the winner is the company which is more dynamic and powerful). At the same time, it should be noted that sometimes tigers go for alternates, but the forest remains the same i.e. dynamic markets; Table 2 shows this competition matrix.

TABLE II. COMPETING WITH DIFFERENT ABSORPTIVE CAPACITIES(SAC AND DAC) AGAINST COMPETITORS ABSORPTIVE CAPACITY (SAC AND DAC)

\begin{tabular}{|c|c|c|c|}
\hline \multicolumn{4}{|c|}{ Competitors AC } \\
\hline \multirow{3}{*}{$\begin{array}{l}\text { Firms } \\
\text { AC }\end{array}$} & & SAC-RBV & DAC-DCV \\
\hline & SAC-RBV & $\begin{array}{l}\text { Business Fight } \\
\text { Based on unique } \\
\text { resource } \\
\text { Bulls fight }\end{array}$ & $\begin{array}{c}\text { Business Fight } \\
\text { based on resources }\end{array}$ \\
\hline & DAC-DC & $\begin{array}{l}\text { Business Fight } \\
\text { Based on skills } \\
\text { and adapting } \\
\text { changing } \\
\text { knowledge }\end{array}$ & $\begin{array}{c}\text { Business Fight } \\
\text { Tigers fight }\end{array}$ \\
\hline
\end{tabular}

\section{B. Firms with Business Mate Option}

The firms have differing absorptive capacity and compete with competitors with different absorptive capacities, however, there are situations when a firm's resources and capabilities mismatch. This results in insufficiency for meeting market demands. Firms now have to reshape their innovation patterns on the basis of their market competition through knowledge networks [26, 27]; this is the critical moment for thinking about collaboration with other firms. Similarly, when knowledge overflows and capabilities (dynamic absorptive capacity) become underutilized, they invite other firms to collaborate with them in order to maximise their profits. Both situations create win-win situations for both mating companies. However, like all business rules, business mate has some too. A few considerations/characteristics before opting for 
business mate must be kept under consideration; Table 3 describes these considerations.

TABLE III. CHARACTERISTICS OF BUSINESS MATE

\begin{tabular}{|l|l|}
\hline Characteristics & Description \\
\hline Type of firm & $\begin{array}{l}\text { Whether the firm deals with routines and pro- } \\
\text { cesses similar to firms }\end{array}$ \\
\hline History of firms & Success rate or profile of firm in the past \\
\hline $\begin{array}{l}\text { Reputation of } \\
\text { firm }\end{array}$ & Is the firm worth mating or otherwise \\
\hline Method of mate & Whether mating is co-evolution or merging. \\
\hline $\begin{array}{l}\text { Risks related to } \\
\text { Type I and } \\
\text { Type II error }\end{array}$ & $\begin{array}{l}\text { It is about selection of firms for mating, keeping } \\
\text { in view own scope and scope of the firms for } \\
\text { mating. Rejecting the "mate fit" firms ( Type I } \\
\text { error) and accepting "mate misfit" firms ( Type } \\
\text { II error ) }\end{array}$ \\
\hline $\begin{array}{l}\text { Cost effective- } \\
\text { ness }\end{array}$ & $\begin{array}{l}\text { Whether the mating will result into a win-win } \\
\text { situation for both firms with cost effective solu- } \\
\text { tion or otherwise. }\end{array}$ \\
\hline
\end{tabular}

Firms deciding to mate with others on the basis of their capabilities (absorptive capacity, both static and dynamic) keep in view the absorptive capacity of firms to whom they have to mate with. The differences in AC on both sides help in deciding whether to opt for available mating options. A description of mating options for firms with static and dynamic absorptive capacities of both firms is now explained and shown in the mating matrix, shown in Table 4.

1) Business Mate in context to Static Absorptive Capacity Vs Static Absorptive Capacity

Firms which possess unique resources, yet are unable to process these to meet market demands, effectively fall in to this category. These firms are either unable to compete with their competitors, due to lagging behind in the market by not fulfilling market demands, or lack in the acquisition of accurate knowledge to enhance their resource base. In both cases, the absorptive capacity of the firm is compromised. Thus, to stay in business, these firms merge with other firms, as the resources and processes of both companies are almost the same. The firms co-evolve, as the mating method with other firms develops. Reasons to mate include:

- Limited resources, although unique but are insufficient to meet high market demands;

- Enhancement in existing absorptive capacity; and

- Sharing of non-overlapping expertise and resources.

2) Business Mate in context to Static Absorptive Capacity Vs Dynamic Absorptive Capacity

In this category, firms with static absorptive capacity are unable to compete with their competitors, both in a static and dynamic market; these firms opt to mate with other firms in possession of dynamic absorptive capacity. The competitors offer their unique resources and capabilities to the firms in the dynamic business environment to compete in the market together. Firms in possession of unique resources, but underdeveloped capabilities, lead to a mismatch between market demand and product specifications. Firms experiencing this, may approach firms with DC for business mating to have a win- win situation. Pakistan Telecom (Paktel) once had a strong market position in the era of analog technology, but during the introduction of GSM technology, its RBV approach was unable to meet changing market demands and it merged with a
Chinese company called Zong Telecom; these companies shared their resources and infrastructures. Now, Zong Telecom is competing with other telecom companies operating in Pakistan, such as Nokia, Ufone and Warid telecoms. The selection of the right business mate leads them to obtain sufficient market share and still remain competitive. Firms may offer their services or core resources to mating partners or have a deal with them in a wholesome way. It depends upon the mating conditions and the pre-established understanding between both parties.

3) Business Mate in context to Dynamic Absorptive Capacity Vs Static Absorptive Capacity

In this category, firms possess strong capabilities to compete in the dynamic market and in changing market conditions with dynamic absorptive capacity. Firms offer other firms, with under developed absorptive capacity, the opportunity to merge with them and attribute to the dynamic absorptive capacity. From another perspective, firms with dynamic capabilities look towards improved strategic positions as their long term objectives, and outsource their business segments falling into RBV domain with well established procedures and uniqueness in resources. Firms with dynamic AC choose to mate with firms that possess static absorptive capacity in the light of their gaps required to be filled, which are time consuming and require unique resources. In this case, these firms choose firms possessing static AC which best suit their processes. Microsoft, one of the largest software companies in the world, has merged with many local developers, such as Nokia mobile phones, Skype technologies, PowerPoint and Web TV network. In the consumer airline industry, Continental Airlines possessed static absorptive capacity and so decided to merge with United Airlines which had dynamic AC; Continental Airlines no more exists and new merged air lines are known with the name of United Airlines.

Both organisations have the choice to accept each other and decide if the match would suit them technically and as per their corporate policies. Firms may accept a portion of resources from one another in the processes as part of the business mate process.

4) Business Mate in context to Dynamic Absorptive Capacity Vs Dynamic Absorptive Capacity

In this category, firms having dynamic absorptive capacity opt to mate with businesses at par with them (firms with dynamic absorptive capacity). In this environment, market demands and product designs change very fast and firms have to follow these changing market trends accordingly. The balance between exploration (acquisition and assimilation) and exploitation leads the firms to achieve their goals effectively; this requires $\mathrm{AC}$ to be upgraded constantly which requires resources and intellectual capital from both organisations. Organisations in this category possess dynamic AC on an equal footing with minor differences. They require business mating to get market share in a cost effective way and improve their strategic position, as fighting in isolation leads them to exhaust their resources and efforts without gaining. Therefore, they decide to collaborate without losing identity i.e. they coevolve in business by pooling their resources and dividing the domains of operation in their business plan and integrating the efforts of both, before entering into the market. Examples of business mating with dynamic absorptive 
capacity, include Hewlett-Packard and Compaq computer corporations, and JAVA and ORACLE. Sometimes the business mate firms go change their corporate name after mating, for example Bell Atlantic with GTE co-evolved with a new identity entitled Verizon Communications.

Firms focus on cost effective solutions which at times become less-feasible, as specialized resources are difficult to manage by solo firms and they go for business mate. Firms may choose the business mate option in this category due to the following reasons:

- Tough and changing market demands;

- Complication in product designs and processes;

- Scarce resources, both tangible and intangible;

- Insufficient competence level, as required for product development in fast changing market;

- $\quad$ Risk factor both in failure of product and high development cost;

- Volatile marketplace; and

- $\quad$ Sharing of diverse expertise.

TABLE IV. BUSINESS MATE WITH DIFFERENT ABSORPTIVE CAPACITIES (SAC AND DAC)

\begin{tabular}{|c|c|c|c|}
\hline \multicolumn{2}{|c|}{} & \multicolumn{2}{c|}{ Competitors AC } \\
\hline \multirow{4}{*}{$\begin{array}{c}\text { Firms } \\
\text { AC }\end{array}$} & SAC- & SAC-(RBV) & DAC-(DC) \\
\cline { 2 - 4 } & RBV) & $\begin{array}{c}\text { Business Mate } \\
\text { Co-evolve }\end{array}$ & $\begin{array}{c}\text { Business Mate } \\
\text { Merge-be chosen }\end{array}$ \\
\cline { 2 - 4 } & DAC-(DC) & $\begin{array}{c}\text { Business Mate } \\
\text { Merge-choose }\end{array}$ & $\begin{array}{c}\text { Business Mate } \\
\text { Co-evolve }\end{array}$ \\
\hline
\end{tabular}

\section{IMPLICATIONS/EXPLANATORY ANALYSIS}

Organisations face two types of business environment: one which is volatile (dynamic) and stable; both environments demand changes in a company's product range. Firms, while keeping in mind the business environment they're operating in, focus on key resources and capabilities (absorptive capacity) for competing with their rivals. For effective competition, analysis of existing AC and enhancement in it for future need is the first step which must be taken.

This paper highlights the differences between absorptive capacities (static and dynamic) which may be used by managers during the formulation of their business strategies. The competition matrix argued in this paper might lead organisational decision makers to re-think their resources and capabilities before putting their firms into competition; it may also be useful for first-line and middle management to evaluate absorptive capacity in context to processes and routines inside their firms.

After the evaluation of resources, managers must seek input for business mating in case they do not fall into the competition matrix. Business mating is argued to be helpful in evaluating key resources for augmentation with others and vice versa to obtain market share indirectly. Additionally, this paper provides an input to gauge the potential of rival firms for competition as well as business mates for future joint ventures.

\section{CONCLUSIONS AND FURTHER WORK}

This paper highlights the differences between static and dynamic absorptive capacity along with resource based view and dynamic capabilities view. The absorptive ca- pacity of firms lead them to identify their potential for competition in dynamic business environments, which further leads them to decide either to compete with rivals or go for business mate with other firms i.e. collaboratively work together. Firms with differing levels of absorptive capacity compete with one another having different options in the context of RBV and DC view. Firms which cannot compete may opt for different business mates based on their absorptive capacity and key resources.

This paper introduces new insights of absorptive capacity and options available for firms (compete or mate). In future, studies should explore the options available for firms, such as potential environments for competition, and methods for effective business mating, based on absorptive capacity.

\section{REFERENCES}

[1] N.J. Foss, "The Resource-Based Perspective: An Assessment and Diagnosis of Problems" Scandinavian Journal of Management, vol. 14 no. 3, pp. 133-149, 1998. http://dx.doi.org/10.1016/S09565221(97)00030-4

[2] B. Wernerfelt, "A Resource-Based View of the Firm" Strategic Management Journal, vol. 5 no. 2, pp. 171-180, 1984. http://dx.doi.org/10.1002/smj.4250050207

[3] J. Barney, "Firms Resources and Sustained Competitive Advantage" Journal of Management, vol. 17 no. 1, pp. 99-120, 1991. http://dx.doi.org/10.1177/014920639101700108

[4] E. Penrose, The Theory of the Growth of the Firm. New York, USA: John Wiley \& Sons Inc., 1959.

[5] K.R. Connor and C.K. Prahalad, "A Resource-Based Theory of the Firm: Knowledge Versus Opportunism" Organization Science, vol. 7 no. 5, pp. 477-501, 1996. http://dx.doi.org/10.1287/ orsc.7.5.477

[6] J.D. Teece, G. Pisano and A. Shuen, "Dynamic Capabilities and Strategic Management" Journal of Strategic Management, vol. 18 no. 7, pp. 509-533, 1997. http://dx.doi.org/10.1002/(SICI)10970266(199708)18:7<509::AID-SMJ882>3.0.CO;2-Z

[7] R. D'Aveni, Hypercompetition: Managing the Dynamics of Strategic Management. New York, USA: Das Summa Summarum des Management, 1994.

[8] W.M. Cohen and D. Levinthal, "Absorptive Capacity: A New Perspective on Learning and Innovation" Administrative Science Quarterly, vol. 35 no. $1, \quad$ pp. 128-152, 1990. http://dx.doi.org/10.2307/2393553

[9] G. Johnson, K. Scholes and R. Whittington, Exploring Corporate Strategy: Text and Cases. Oxford, UK: Pearson Education, 2008.

[10] M.A. Peteraf, "The Cornerstones of Competitive Advantage: A Resource-Based View" Strategic Management Journal, vol. 14 no. 3, pp. 179-191, 1993. http://dx.doi.org/10.1002/smj.42 $\underline{50140303}$

[11] I. Dierickx and K. Cool, "Asset Stock Accumulation and Sustainability of Competitive Advantage" Journal of Management Science, vol. 35 no. 12, pp. 1504-1511, 1989. http://dx.doi.org/10.1287/mnsc.35.12.1504

[12] R. Makadok, "Toward a Synthesis of the Resource-Based and Dynamic-Capability Views of Rent Creation" Strategic Management Journal, vol. 22 no. 5, pp. 387-401, 2001. http://dx.doi.org/10.1002/smj.158

[13] K. Christensen and L. Fahey, "Building Distinctive Competences into Competitive Advantage" Strategic Planning Management, vol. 2, pp. 113-123, 1984.

[14] J. Nieves and S. Haller, "Building Dynamic Capabilities through Knowledge Resources" Tourism Management, vol. 40, pp. 224232, 2014. http://dx.doi.org/10.1016/j.tourman.2013.06.010

[15] S.A. Zahra and G. George, "Absorptive Capacity: A Review, Reconceptualisation and Exension" The Academy of Management Review, vol. 27 no. 2, pp. 185-203, 2002.

[16] J.J.P. Jansen, F.A.J. Van Den Bosch and H.W. Volberda, "Managing Potential and Realised Absorptive Capacity: How do Organisational Antecedents Matter" Academy of Management Journal, 
vol. 48 no. 6, pp. 999-1015, 2005 http://dx.doi.org/10.5465/ AMJ.2005.19573106

[17] D. Minbaeva, T. Pedersen, I. Bjorkman, C.F. Fey and H.J. Park, "MNC Knowledge Transfer, Subsidiary Absorptive Capacity and HRM" Journal of International Business Studies, vol. 34 no. 6, pp. 586-599, 2003. http://dx.doi.org/10.1057/palgrave.jibs.8400056

[18] J.L. Ferreras-Mendez, S. Newell, A. Fernandez-Mesa and J. Alegre, "Depth and Breadth of External Knowledge Search and Performance: The Mediating Role of Absorptive Capacity" Industrial Marketing Management, vol. 47, pp. 86-97, 2015. http://dx.doi.org/10.1016/j.indmarman.2015.02.038

[19] K. Sakhdari, H. Burgers and P. Davidsson, "Capable but not able: The Effect of Institutional Context and Search Breadth on the Absorptive Capacity-Corporate Entrepreneurship Relationship," Proceedings of the Australian Centre for Entrepreneurship Research Exchange Conference, pp. 954-974, May 2014.

[20] V. Moreno, J.R.M. Pinheiro, L.A. Joia and F. Cavazotte, "Managerial Capacity, Absorptive Capacity and the Performance of Small Software Companies," Proceedings of the Academy of Management, Paper ID: 10634, 2014. http://dx.doi.org/10.5465/ ambpp.2014.10634abstract

[21] M. Rafique, M.T. Nawaz, R.D. Evans and M. Agha, "Analysing Success Factors in the Development of Absorptive Capacity in Pharmaceutical Companies based in Pakistan," Proceedings of the International Conference on Business Administration, pp. 235239, Feb 2015.

[22] C. Camison and B. Forbes, "Knowledge Absorptive Capacity: New Insights for its Conceptualization and Measurement" Journal of Business Research, vol. 63 no. 7, pp. 707-715, 2010. http://dx.doi.org/10.1016/j.jbusres.2009.04.022

[23] F. Khoja and S. Maranville, "How do firms nurture absorptive capacity?" Journal of Managerial Issues, vol. 22 no. 2, pp. 262278, 2010.

[24] H. Gebauer, H. Worch and B. Truffer, "Absorptive Capacity, Learning Processes and Combinative Capabilities as Determinants of Strategic Innovation" European Management Journal, vol. 30 no. 1, pp. 57-73, 2012. http://dx.doi.org/10.1016/j.emj. $\underline{2011.10 .004}$

[25] A. Protogerou, Y. Caloghirou and S. Lioukas, "Dynamic Capabilities and their Indirect Impact on Firm Performance" Industrial and Corporate Change, vol. 21 no. 3, pp. 615-647, 2012. http://dx.doi.org/10.1093/icc/dtr049

[26] J. Song, "Subsidiary Absorptive Capacity and Knowledge Transfer within Multinational Corporations" Journal of International Business Studies, vol. 45 no. 1, pp. 73-84, 2014. http://dx.doi.org/10.1057/jibs.2013.55

[27] E. Enkel and S. Heil, "Preparing for Distant Collaboration: Antecedents to Potential Absorptive Capacity in Cross-Industry Innovation" Technovation, vol. 34 no. 4, pp. 242-260, 2014. http://dx.doi.org/10.1016/j.technovation.2014.01.010

\section{AUTHORS}

Muhammad Rafique is with National University of Science and Technology, Islamabad, Pakistan (raf.sibi@ceme.nust.edu.pk).

Richard David Evans is with University of Westminster, UK (R.Evans@westminster.ac.uk).

Muhammad Tahir Nawaz is with National University of Science and Technology, Islamabad, Pakistan (hodem@ceme.nust.edu.pk).

Mujtaba Hassan Agha is with Muhammad Ali Jinnah University, Islamabad, Pakistan (mujtaba.agha@jinnah.edu.pk).

Submitted 21 May 2015. Published as resubmitted by the authors 30 August 2015. 